\title{
PEMBINAAN METODE BELAJAR DARI RUMAH BAGI WALI MURID SD YAPIS 2 BIAK PADA MASA PANDEMIK COVID-19
}

\author{
Busyairi Ahmad'), Hamjah Bonso"), Samsiah ${ }^{3)}$ \\ 1)Program Studi Sosiologi, FISIP, IISIP Yapis Biak, Papua, Indonesia \\ 2) Program Studi IImu Pemerintahan, FISIP, IISIP Yapis Biak, Papua, Indonesia \\ 3)Program Studi Administrasi Perkantoran, FIA, IISIP Yapis Biak, Papua, Indonesia \\ Corresponding author : Busyairi Ahmad, Hamjah Bonso, Samsiah \\ E-mail : busyairiahmad90@gmail.com
}

Diterima 05 April 2021, Direvisi 08 April 2021, Disetujui 09 April 2021

\begin{abstract}
ABSTRAK
Pengabdian kepada Masyarakat ini bertujuan untuk meberikan pembinaan terhadap wali murid SD YAPIS 2 Biak dalam membimbing anak-anaknya untuk belajar di rumah agar pembelajaran di rumah epektif sesuai harapan bersama. Metode pelaksanaan menggunakan survei dan bimbingan metode belajar bagi wali/orangtua murid secara offline namun mengikuti protokol Kesehatan yang telah diatur pemerintah. Peserta pembinaan terdiri dari enam kelompok yaitu kelompok wali murid kelas I sampai dengan kelas $\mathrm{VI}$, masing-masing kelompok terdiri dari 10 peserta. Hasil pengabdian kepada masyarakat diperoleh sebagai yaitu wali murid; a) memahami cara membimbing anak berdasarkan tugas yang diberikan oleh guru, b) mengetahui cara memahami materi dan cara menjawab soal dari buku yang telah diberikan dari sekolah untuk membimbing anaknya, c) mengetahui cara mengatur waktu untuk membimbing anak dalam mengerjakan tugas dan belajar membaca, menulis bagi siswa kelas I.
\end{abstract}

Kata kunci: pembinaan; metode belajar dari rumah; wali murid; masa pandemi covid-19.

\begin{abstract}
This community service aims to provide guidance to the guardians of SD YAPIS 2 Biak students in guiding their children to study at home so that learning at home is effective according to common expectations. The implementation method uses surveys and learning method guidance for parents/ guardians of students offline but follows the Health protocol that has been regulated by the government. The coaching participants consist of six groups, namely the guardian group of grade I to class $\mathrm{VI}$ students, each group consisting of 10 participants. The results of community service are obtained as guardians of students; a) understand how to guide children based on assignments given by the teacher, b) know how to understand the material and how to answer questions from books that have been given from school to guide their children, c) know how to manage time to guide children in doing assignments and learning to read, writing for grade I students.
\end{abstract}

Keywords: coaching; home learning method; student guardian; the covid-19 pandemic period.

\section{PENDAHULUAN}

Pandemik Covid-19 merupakan bencana multidimensi yang melumpuhkan sendi-sendi kehidupan termasuk didalamnya aspek pendidikan. Sebagai upaya preventive maupun kurative Kementrian Pendidikan Dan Kebudayaan (KEMENDIKBUD) menerapkan kebijakan belajar dari rumah (BDR) pada seluruh jenjang pendidikan, pada tingkat sekolah dasar (SD) belajar dari rumah tentunya menjadi sesuatu yang luar biasa berbeda dan memiliki tantangan tersendiri, anak-anak usia dini yang notabenenya memahami sekolah sebagai konsep bersosialisasi, belajar dan bermain bersama dengan teman-teman di sekolah dipaksa untuk menerima realitas baru belajar darirumah lalu peran guru diambil alih oleh orangtua/wali, keadaan inipun mutlak menjadi pekerjaan rumah yang luar biasa bagi orangtua/wali yang sebelumnnya merasa aman dan nyaman menitipkan pengajaran dan pembimbingan anak pada guru dan sekolah kemudian dituntut untuk mengambil alih peran mengajar, mengarahkan, membimbing, mengevaluasi bahkan tidak jarang dipusingkan dengan tugas atau pekerjaan rumah yang harus diunggah secara online, berbagai permasalahan terjadi dikala orangtua yang juga harus bekerja dari rumah dituntut berperan ganda sebagai guru multidisiplin ilmu lalu fenomena lain adalah adaptasi pembelajaran berbasis digital yang benar-benar memaksa orang tua untuk berpikir keras dan berusaha keras memenuhi harapan belajar ideal dirumah baik dari segi penguasaan technology maupun penyediaan quota data untuk akses internet. 
Pandemik Covid-19 menciptakan perubahan secara cepat yang bersifat memaksa akibatnya banyak orangtua dan murid menjadi tidak siap, latah dan tidak sedikit menjadi stress dengan adaptasi kebiasaan baru belajar dari rumah, kondisi ini kemudian bermunculan kasus BLAST (Bored, Lonely, Angry and Afraid ,Stress, Tired) yakni kondisi rapuhnya mental anak-anak akibat beban belajar yang berubah drastic kebosanan, marah, stress dan lelah sebagai dampak belajar mandiri dirumah.

Selanjutnya, Orang tua yang mendampingi menjadi tidak sabar, tidak peka, dan terkadang memaksakan kehendak karena tidak adanya bekal ilmu mendidik yakni kompetensi paedagogik, sosial, profesionalisme dan kepribadian yang merupakan cikal bakal pengajaran menyenangkan dan bermakna, sehingga tak jarang kegiatan belajar mengajar dirumah dibumbui dengan kekerasan fisik dan psikis yang pada akhirnya berimbas pada kesehatan mental anak, hal ini tentunya menjadi ironi disatu sisi kebijakan belajar dari rumah menjadi alasan untuk menjaga kesehatan dan penularan Covid-19 namun disatu sisi memunculkan patologi dalam proses belajar itu sendiri yakni kerugian dari segi kesehatan mental anak. Dimana seharusnya menurut Heath and Bainbridge (Esty Pamungkas et al., 2020) Pemberian stimulasi dini yang sesuai akan memungkinkan terbentuknya etika, kepribadian yang baik, kecerdasan, kemandirian, keterampilan dan produktivitas yang baik. Namun dengan munculnya Covid-19 tidak jarang orang tua memarahi anak saat membimbing belajar dirumah.

Adapun hakekat pendidikan menurut Jamaris (Winarti, 2020) adalah menyediakan lingkungan yang aman bagi perkembangan anak karena di dalam lingkungan yang aman tersebut anak dapat mengembangkan berbagai potensi yang dimilikinya dengan baik. Selanjutnya fungsi keluarga adalah sebagai pendidikan budi pekerti, sosial, kewarganegaraan, pembentukan kebiasaan dan pendidikan intelektual anak (Jailani, 2014).

Namun dari hal tersebut di atas, tidak jarang orang tua tidak memiliki modal pengetahuan dalam membina intelektial anak sehingga banyak orang tua yang belum mampu untuk membimbing anaknya dalam hal ini belajar di rumah, sehingga hal tersebut menjadi kendala orang tua dalam membimbing anak dalam belajar.

Oleh karena itu, selaku akademisi yang memiliki kepedulian dalam hal Pendidikan maka sangat penting untuk menjadi perhatian semua kalangan dalam membina wali murid dalam membekali metode pembelajaran dirumah. Karena pelaksanaan belajar dari rumah saat ini tak jarang memunculkan masalah, orangtua maupun anak-anak dihadapkan pada perubahan kebiasaan secara cepat sehingga tidak adanya kesiapan fisik maupun mental memicu timbulnya berbagai kesenjangan antara harapan dan realitas yang terjadi, tentunya untuk membenahi masalah ini dibutuhkan pembinaan terhadap pihak terkait yakni wali/orangtua murid melalui kegiatan pengabdian kepada masyarakat (PKM) sebagai bagian dari bentuk tanggungjawab dan Tri Dharma Perguruan Tinggi oleh dosen IISIP YAPIS BIAK dengan lokasi mitra binaan pada SD YAPIS 2 Kabupaten Biak Numfor.

Pada tahap observasi awal baik berupa wawancara maupun telaah dokumentasi terhadap mitra binaan ditemukan beberapa situasi tidak jauh berbeda dengan situasi belajar dari rumah diberbagai daerah di Indonesia hal ini kemudian disebabkan oleh tiga faktor utama yakni: a). Faktor beban kerja ganda (double burden), Orangtua yang juga bekerja/ berkarir dihadapkan pada situasi serba sulit ketika harus berperan ganda sebagai pekerja yang Bekerja Dari Rumah (WFH) dan sebagai guru mengajar anak Belajar Dari Rumah (BDR), peran mendampingi anak terkadang terekstradiksi dengan beban pekerjaan yang juga dikerjakan di rumah, penelitian terkait dengan masalah ini mengemukakan bawha orang tua memiliki peran utama selama masa belajar dirumah. Orang tua adalah tempat pertama yang mengetahui perkembangan anak menjadi kontrol dan guru anak selama di rumah. Sehingga bisa disimpulkan bahwa situasi ini mengakibatkan bertambahnya beban dan tanggungjawab orangtua (Nahdi et al., 2020).

Selanjtnya, b). Faktor Kapasitas peran (human capacity). Orangtua sulit memenuhi peran sebagai seorang guru yang ideal dikarenakan tidak semua orang tua memiliki latar belakang pendidikan keguruan ataupun berpendidikan. Perlu diperhatikan bahwa standar nasional pendidikan mensyaratkan empat kompetensi dasar yang harus dimiliki oleh seseorang jika ingin menjadi seorang guru yang baik. Yakni kompetensi paedagogik atau kemampuan mengajar, kompetensi profesional yang ditandai dengan gelar keguruan, kompetensi social yakni kemampuan bersosialisasi dan kompetensi pribadi yakni kepribadian seorang guru yang menjadi panutan. Kompetensi yang dimiliki seorang guru berpengaruh positif terhadap kinerja guru (Elfrida et al., 2020).

Adapun factor ketiga, c). Faktor ekonomi (economic factor), kondisi keuangan 
rumah tangga yang menjadi sulit memenuhi kebutuhan belajar dari rumah berupa perlatan prakarya, alat peraga dan quota data internet yang menjadi penunjang BDR. Resesi ekonomi yang terjadi akibat Covid-19 berdampak pada rendahnya sentimen investor terhadap pasar yang pada akhirnya membawa pasar ke arah cenderung negatif hal ini kemudian menyebabkan Lambatnya ekonomi global yang berdampak terhadap pertumbuhan perekonomian Indonesia (Nasution et al., 2020). Ketiga faktor di atas berpengaruh terhadap psikologis orang tua dalam membimbing anak di rumah karena dengan kesibukan orang tua juga dapat berdampak terhadap emosional orang tua. Sehingga sering sekali terjadi kekerasan orang tua terhadap anak Ketika mendidik atau membimbing anak di rumah baik membaca, mengerjakan tugas dan sebagainya.

Selain itu, terdapat beberapa permasalahan yang sangat urgent bagi orang tua dalam membimbing anak belajar di rumah selama pandemic covid-19 yaitu proses belajar pengalaman dan bermakna tidak berjalan efektif dikarenakan kurangnya waktu yang bisa diberikan orangtua dalam mendampingi anak saat belajar, Ketidakmampuan orangtua dalam memahami dan mengajarkan berbagai mata pelajaran berbeda serta kesulitan adaptasi belajar berbasis teknologi digital menimbulkan masalah emosional yang terkadang berujung pada keputusasaan, tidak peduli dan antipati pada permintaan atau pertanyaan anak saat belajar, dan yang terakhir belajar dari rumah artinya segala sesuatu baik alat, media maupun perangkat untuk mendukung proses belajar disediakan secara mandiri oleh wali dan murid, namun kondisi ini menjadi masalah ketika orang tua tidak mampu secara ekonomi untuk memenuhi kebutuhan belajar tersebut.

Oleh karena itu, salah satu metode yang tepat digunakan orang tau dalam membimbing anak belajar di rumah adalah dengan menggunakan metode eja bagi orang tua murid kelas I, gunanya adalah untuk mengajar anak membaca di rumah. Selanjtnya bagi mata pelajaran lain dan untuk kelas 1 sampai dengan kelas 6 menggunakan metode belajar berbasis lingkungan, manfaat dari metode ini adalah membantu siswa menemukan makna dari lingkuan tersebut yang disesuaikan dengan materi tugas atau mata pelajaran yang diberikan dari sekolah.

Adapun tujuan dari pengabdian ini adalah untuk memberikan bekal pengetahuan tentang metode bagi orang tua murid untuk membantu guru dalam proses belajar dan meningkatkan kemampuan siswa.

\section{METODE}

Pelaksanaan pengabdian ini dilaksanakan sejak tanggal 25 januari hingga 30 mei. Adapun pengabdian ini dilaksanakan di 6 titik lokasi di kelurahan Samofa yaitu di RT 1 sampai dengan RT 6. peserta wali murid sebanyak 63 peserta yang dibagi menjadi 6 kelompok, dari 63 peserta dominan ibu-ibu rumah tangga. Penentuan dari 63 peserta tersebut berdasarkan data dari sekolah SD Yapis 2 Biak Numfor dan tim pengabdi menngunakan teknik ramdom sampling.

Metode yang digunakan pada pelaksanaan PKM ini berbasis program kemitraan dimana tim pengusul dari IISIP YAPIS BIAK menggandeng SD YAPIS 2 BIAK dalam pelaksanaan pembinaan metode belajar dari rumah bagi wali/orangtua murid adapun rencana PKM dijabarkan kedalam 3 tahap yakni pelaksanaan solusi, partisipasi mitra, dan evaluasi pelaksanaan program. Berikut uraian setiap metode yang ditempuh sebagai berikut:

\section{Langkah-langkah pelaksanaan}

Tahap awal yakni pengambilan dan pengumpulan data mitra pada SD YAPIS 2 BIAK 1.2.Tahap observasi yakni menelisik fenomena dan realitas yang terjadi di masyarakat khususnya siswa siswi SD 2 YAPIS BIAK. Tahap kedua Pendekatan dan sosialisasi PKM kepada mitra. Tahap ketiga Konseling atau bimbingan metode belajar bagi wali/orangtua murid. Kunjungan/visit home untuk pembinaan mendalam terhadap mitra. Tahap keempat yaitu Evaluasi kegiatan.

\section{Partisipasi mitra}

Adapun yang menjadi mitra dalam pengabdian ini adalah sekolah SD Yapis 2 Biak Numfor. Sebagai objek binaan mitra secara kooperatif memberikan data yang diperlukan dalam proses pembinaan. Berpartisipasi dan bergabung dalam komunitas class parenting, mengikuti seminar dan bimbingan metode belajar dari rumah, secara aktif memberikan informasi perkembangan dan hasil pembinaan mitra.

\section{Evaluasi dan kelanjutan PKM}

Evaluasi adalah pengukuran dan
perbaikan suatu kegiatan, seperti membandingkan hasil kegiatan dan menganalisisnya.dalam PKM ini jenis evaluasi yang dipergunakan ada 2 yakni:

1) Evaluasi diagnostik berfungsi atau dilaksanakan untuk mengidentifikasi kesulitan belajar yang dialami peserta didik, menentukan faktor-faktor yang menyebabkan terjadinya kesulitan berlajar, dan menetapkan cara mengatasi 
kesulitan berlajar tersebut,sehingga diharapkan setelah dilakukan pembinaan ada hasil peningkatan kualitas belajar yang dicapai

2) Evaluasi formatif pada dasarnya adalah evaluasi proses yang bertujuan untuk mendapatkan umpan balik bagi usaha perbaikan kualitas pembelajaran dalam konteks kelas. (Sumintono \& Widhiarso, 2015) umpan balik yang diharapkan untuk mengukur keberhasilan pelaksanaan pembinaan melalui wawancara dan Tanya jawab terhadap mitra.

\section{HASIL DAN PEMBAHASAN}

Pembinaan Metode Belajar Dari Rumah Bagi Wali Murid SD YAPIS 2 BIAK Pada Masa Pandemik COVID-19

Peserta pembinaan wali murid SD Yapis 2 Biak Numfor sebanyak 63 peserta yang dibagi dalam 6 kelompok, sebagaimana yang dijabarkan pada tabel berikut:

Tabel 1. Peserta pembinaan berdasarkan kelas dan pembagian kelompok.

\begin{tabular}{ccc}
\hline Kelas & $\begin{array}{c}\text { Jumlah } \\
\text { Peserta }\end{array}$ & Kelompok \\
\hline I & 13 & 1 \\
\hline II & 10 & 2 \\
\hline III & 10 & 3 \\
\hline IV & 10 & 4 \\
\hline V & 10 & 5 \\
\hline VI & 10 & 6 \\
\hline Jumlah & $\mathbf{6 3}$ & $\mathbf{6}$ \\
\hline
\end{tabular}

Berdasarkan tabel 1 di atas menunjukkan bahwa peserta dalam pembinaan wali murid dalam memahami metode belajar di rumah adalah sebangak 63 peserta yang terdiri dari ibu-ibu rumah tangga. Adapun jumalah tersebut adalah hasil dari random sampling dari kesekian jumlah wali murid yang ada di SD Yapis 2 Biak, memngingat waktu dan biaya maka pelaksana pengabdian merandom dari masing-masing kelas. Dengan kriteria yang telah ditentukan yaitu ibu-ibu rumah tangga yang tidak memiliki pekerjaan dan memiliki pekerjan tapi bukan pegawai suwasta dan PNS.

\section{Pelaksanaan Pembinaan Metode belajar dari Rumah}

Berdasarkan pengelompokan peserta/ wali murid yang diberikan pembinaan metode berdasarkan kelas di atas maka pada tahap pelaksanaan pembinaan tim pengabdian membagi tahap lekasanaan menjadi tiga tahap sebagaimana yang tertera pada tebel berikut ini:
Tabel 2 Tahap Pelaksanaan Pembinaan Metode Pembelajaran Dari Rumah

\begin{tabular}{clc}
\hline Tahap & \multicolumn{1}{c}{ Kegiatan } & \multicolumn{1}{c}{ Ket. } \\
\hline I & Pemberian materi & Kelompok \\
& tentang Jenis & $1 \mathrm{~s} / \mathrm{d} 6$ \\
& Metode Belajar & 6 hari \\
& Tingkat SD & \\
\hline II & Pendampingan & Kelompok 1 \\
& menggunakan & s/d 6 \\
& Metode Belajar & selama 1 \\
& & bulan \\
\hline III & Evaluasi Hasil & Kelompok 1 \\
& Pembinaan & s/d 6 \\
& & Per-individu \\
\hline
\end{tabular}

Berdasarkan tabel 2 di atas, maka penulis dalam hal ini dapat menjelaskan sebagai berikut:

Tahap Pemberian Materi Tentang Jenis Metode Belajar Tingkat SD

Penyampaian materi tentang jenis metode belajar tingkat SD disampaikan oleh beberapa narasumber dari pihak sekolah yaitu Guru Wali Kelas dari kelas 1 sampai dengan kelas 6 secara bergiliran. Pada hari pertama kelompok 1 di sampaikan oleh Guru wali kelas kelas 1 begitu juga seterusnya sampai kelompok 6 . Sehingga pada pelaksanaan ini wali murid dengan guru Wali Kelas akrab dan dapat membantu nantinya dalam kelangsungan pembalajaran di rumah.

Selain itu disampaikan juga oleh tim pelaksana Pengabdian kepada Masyarakat yaitu Busyairi Ahmad, S.Pd.,M.Pd dan ibu Samsiah, S.Pd.,M.Pd. yang di pandu oleh bapak Hamjah Bonso, S.AN.,M.IP. sebagaimana yang tertera pada gambar berikut:

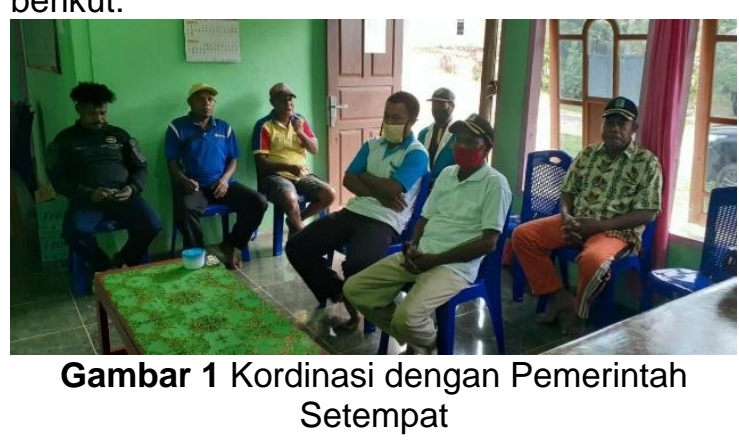

Gambar 1 merupakan dokumentasi saat kordinasi dengan pemerintah kampung beserta RT dan RW mengenai program yang dilakukan di wilayahnya. Kordinasitersebut dialkene dengan tujuan untuk diberikan izin malakukan kegiatan meski kondisi covid19 tentunya berdasarkan protocol Kesehatan yang telah di atur pemerintah. 


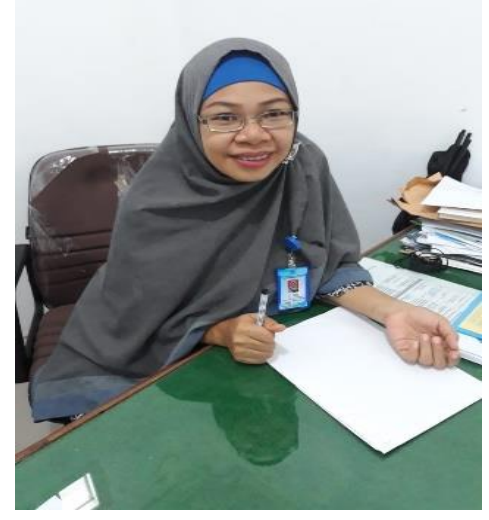

Gambar 2 Pemateri dan sekaligus Tim Pengabdian Kepada Masyarakat

Gambar 2 merupakan salah satu Tim pelaksana Pengabdian sekaligus menjadi pemateri mengani metode belajar di rumah, pada gambar tersebut menunjukkan persiapan materi metode belajar di rumah.

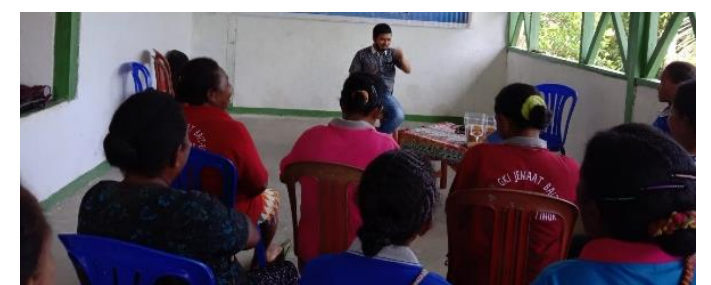

Gambar 3 Pemberian Materi Tentang Metode Balajar di Rumah

Gambar 3 di atas merupakan potret pelaksanaan pengabdian yang dalam hal ini pemberian metari kepada ibu-ibu wali murid mengani metode pembelajaran di rumah guna nantinya dapat diterapkan pada nak-anaknya saat belajar dirumah.

\section{Tahap Pendampingan Menggunakan Metode Belajar \\ Setelah diberikan materi mengenai} metode pembelajarna dirumah oleh tim pengabdian kepada masyarakat beserta guru wali kelas. Selanjutnya tim pengabdian melakukan pendampingan penggunaan metode kepada peserta berdasarkan kelompok yang telah di tentukan tersebut selain itu tim juga melakukan pemantauan selama 3 minggu terhadap peserta dari rumah-kerumah.

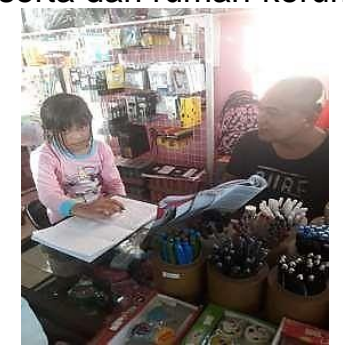

Gambar 4 Pelaksanaan pendampingan wali Murid dari rumah ke rumah.

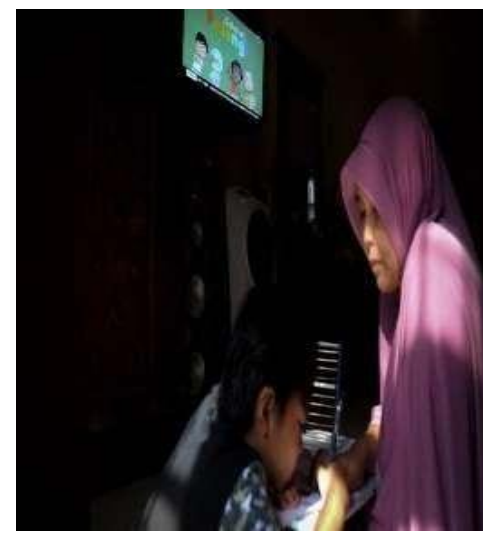

Gambar 5 Pelaksanaan Pendampinag Wali Murid

Pada Gambar 4 dan 5 diatas menunjukkan potret dari pelaksanaan pendampingan kepada wali murid SD Yapis 2 Biak Numfor yang dialkene oleh tim Pengabdian kepada Masyarakat dari rumah-ke rumah peserta pembiann metode tersebut.

Adapun pendampingan dialkene selama 1 bulan dan para tim mendatangi dari rumah kerumah untuk mamantau pelaksanaan pembelajaran di rumah dan metode yang digunakan oleh wali murid alam mengajarkan dan membimbing anaknya di rumah.

Tujuannya adalah untuk memastikan keefektipan pembelajarna berdasarkan tema pengabdian dan materi yang telah di berikan.

\section{Tahap Evaluasi Hasil Pembinaan}

Pengabdian kepada masyarakat ini tidak hanya diberikan pembinaan terhada wali murid dalam membimbing anaknya belajar dirumah. Namun juga melakukan evaluasi keberhasilan dari pengabdian ini.

Adapun hasil dari evaluasi menunjukkan bahwa pembinaan wali murid SD Yapis 2 Biak oleh tim pengabdian adalah berhasil. Adapun teknik dari evaluasi ini menggunakan tes praktik dan tes tulis. Pada tes tulis peserta menjawab soal-soal mengenai teknik mengajar di rumah dan metode mengajar di rumah. Hal dari tes tulis atau menjawab soal adalah:

a) Kelompok 1

Kelompok 1 terdiri dari 13 peserta dan menunjukkan hasil bahwa dari 15 soal tes tulis tersebut 9 peserta memiliki jawaban betul semua dan hasil 100. Sedangankan 2 peserta betul 7 dari 15 soal dan 2 peserta betul 6 dari 15 soal tes.

b) Kelompok 2

Kelompok ke2 menunjukkan bahwa dari 13 peserta dan menunjukkan hasil bahwa dari 15 soal tes tulis tersebut 10 peserta memiliki jawaban betul semua dan hasil 
100. Sedangankan 1 peserta betul 5 dari 15 soal dan 2 peserta betul 7 dari 15 soal tes

c) Kelompok 3

Adapun kelompok ke3 menunjukkan bahwa dari 13 peserta dan menunjukkan hasil bahwa dari 15 soal tes tulis tersebut 8 peserta memiliki jawaban betul semua dan hasil 100. Sedangankan 3 peserta betul 8 dari 15 soal dan 2 peserta betul 5 dari 15 soal tes

d) Kelompok 4

Pada kelompok ke4 menunjukkan bahwa dari 13 peserta dan menunjukkan hasil bahwa dari 15 soal tes tulis tersebut 10 peserta memiliki jawaban betul semua dan hasil 100. Sedangankan 2 peserta betul 7 dari 15 soal dan 1 peserta betul 6 dari 15 soal tes

e) Kelompok 5

Kelompok 5 menunjukkan bahwa dari 13 peserta dan menunjukkan hasil bahwa dari 15 soal tes tulis tersebut 9 peserta memiliki jawaban betul semua dan hasil 100 . Sedangankan 4 peserta betul 7 dari 15 soal tes

f) Kelompok 6

Kelompok ke6 menunjukkan bahwa dari 13 peserta dan menunjukkan hasil bahwa dari 15 soal tes tulis tersebut 9 peserta memiliki jawaban betul semua dan hasil 100 . Sedangankan 2 peserta betul 7 dari 15 soal dan 2 peserta betul 6 dari 15 soal tes

Adapun tes praktik digunakan dengan memberikan kesempatan kepada peserta untuk mengajar dan memahami materi tingkat sekolah dasar dan menjelaskan kepada peserta lainnya yang seolah-olah anaknya. Adapun hasil dari praktikum tersebut menunjuukan bahwa dari 13 peserta 8 peserta persentasi dan penguasaan materinya bagus dan 5 peserta masih kurang.

Berdasarkan dari hasil tes tulis dan praktik tersebut, maka maka dapat disimpulkan bahwa 70\% berhasil dan 30\% kurang berhasil. Dalam hal ini ditunjukkan dalam grafik berikut ini:

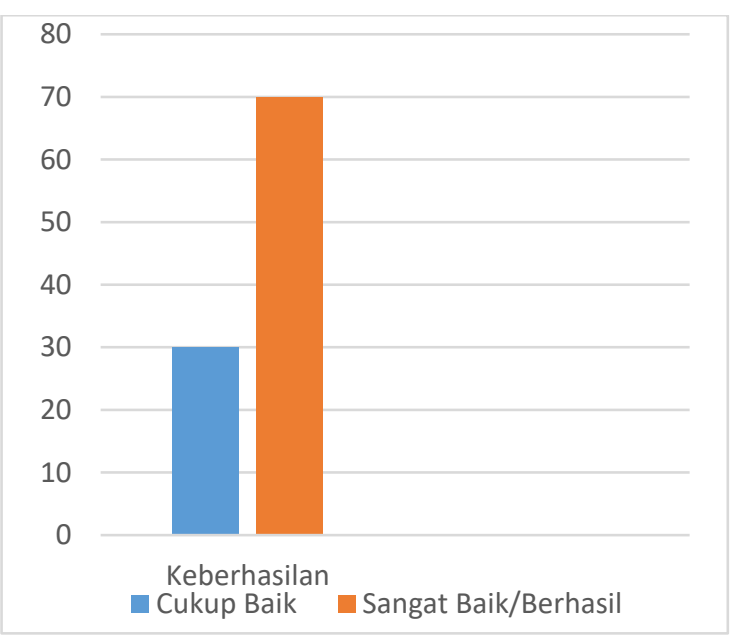

Gambar 6 Hasil Evaluasi Pembinaan Metode Belajar dari Rumah Bagi Wali Murid SD Yapis 2 Biak .

Dari Gambar 6 menunjukkan bahwa terdapat keberhasilan dari pembinaan metode belajar dari rumah bagi wali murid SD Yapis 2 Biak di Masa pandemi Covid-19.

\section{SIMPULAN DAN SARAN}

Isi simpulan dan saran menggunakan huruf dan gaya paragraf yang sama dengan bagian lainnya dan disarnakan ditulis dalam satu paragraf dan menghindari penggunaan bullet dan numbering.

\section{UCAPAN TERIMAKASIH}

Terlaksananya Pengabdian Kepada Masyarakat ini tentunya atas dasar bantuan dan kontibusi dari beberapa pihak diantaranya, Rektor IISIP Yapis Biak, Mitra yaitu Guru SD Yapis 2 Biak, Kepala LP2M IISIP Yapis Biak dan pemerintah terkait terlebih lagi antusias dari peserta pembinaan yang sampai 3 bulan di bina namun tetap bersemangat. Oleh karena itu, tim Pengabdian mengucapkan terimakasih yang setinggi-tingginya atas kontribusinya atas terlaksananya program ini. semoga program ini bermanfaat guna peningkatan kualitas anak negri sebagi tunas bangsa. Selanjutnya bagi penerbit yang telah bersedia dan menerima jurnal ini untuk di terbutkan penulis mengucapkan terimaksih yang setinggitingginya semoga artikel ini bermanfaat bagi khalayak luas berkah dari diterbitkannya dan dapat diakses oleh masyarakat dan pihak yang membutuhkan.

\section{DAFTAR RUJUKAN}

Elfrida, D., Santosa, H., \& Soefijanto, T. A. (2020). Pengaruh Kompetensi Guru dan Implementasi Kurikulum Asing Terhadap Kinerja Guru di Sekolah Internasional Jakarta Utara. Tadbir: 
Jurnal Studi Manajemen Pendidikan. https://doi.org/10.29240/jsmp.v4i1.135 8

Esty Pamungkas, C., Amini, A., \& Rahmawati, C. (2020). SENTUHAN KASIH IBU, UPAYA STIMULASI TUMBUH KEMBANG ANAK DENGAN PIJAT BAYI PADA ANAK USIA 0-3 TAHUN DI DESA SELEBUNG KETANGGA, KECAMATAN KERUAK KABUPATEN LOMBOK TIMUR. SELAPARANG Jurnal Pengabdian Masyarakat Berkemajuan.

https://doi.org/10.31764/jpmb.v4i1.322 3

Jailani, M. S. (2014). Teori Pendidikan Keluarga dan Tanggung Jawab Orang Tua dalam Pendidikan Anak Usia Dini. Nadwa. https://doi.org/10.21580/nw.2014.8.2.5 80

Nahdi, K., Ramdhani, S., Yuliatin, R. R., \& Hadi, Y. A. (2020). Implementasi Pembelajaran pada Masa Lockdown bagi Lembaga PAUD di Kabupaten Lombok Timur. Jurnal Obsesi: Jurnal Pendidikan Anak Usia Dini. https://doi.org/10.31004/obsesi.v5i1.52 9

Nasution, D. A. D., Erlina, E., \& Muda, I. (2020). Dampak Pandemi COVID-19 terhadap Perekonomian Indonesia. Jurnal Benefita. https://doi.org/10.22216/jbe.v5i2.5313

Sumintono, B., \& Widhiarso, W. (2015). Penilaian Pendidikan dan Ujian. AplikAsi Rasch PemodelAn Pada Assessment Pendidikan.

Winarti, A. (2020). Implementasi Parenting Pada Pendidikan Usia Dini di Masa Pandemi Covid-19. JurnalPendidikan PembelajaranPemberdayaan Masyarakat. 